\title{
8
}
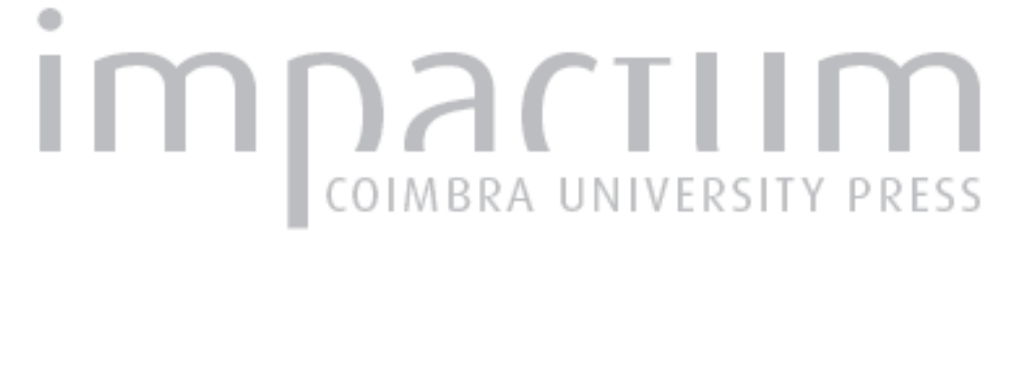

\section{Um breve panorama das relações entre política e religião no contexto do Estado Moderno}

\author{
Autor(es): $\quad$ Casamasso, Marco Aurélio Lagreca \\ Publicado por: Universidade Católica de Petrópolis \\ URL \\ persistente: \\ URI:http://hdl.handle.net/10316.2/33862 \\ DOI: \\ DOI:http://dx.doi.org/10.14195/2175-0947_2-1_3 \\ Accessed : $\quad$ 26-Apr-2023 15:11:46
}

A navegação consulta e descarregamento dos títulos inseridos nas Bibliotecas Digitais UC Digitalis, UC Pombalina e UC Impactum, pressupõem a aceitação plena e sem reservas dos Termos e Condições de Uso destas Bibliotecas Digitais, disponíveis em https://digitalis.uc.pt/pt-pt/termos.

Conforme exposto nos referidos Termos e Condições de Uso, o descarregamento de títulos de acesso restrito requer uma licença válida de autorização devendo o utilizador aceder ao(s) documento(s) a partir de um endereço de IP da instituição detentora da supramencionada licença.

Ao utilizador é apenas permitido o descarregamento para uso pessoal, pelo que o emprego do(s) título(s) descarregado(s) para outro fim, designadamente comercial, carece de autorização do respetivo autor ou editor da obra.

Na medida em que todas as obras da UC Digitalis se encontram protegidas pelo Código do Direito de Autor e Direitos Conexos e demais legislação aplicável, toda a cópia, parcial ou total, deste documento, nos casos em que é legalmente admitida, deverá conter ou fazer-se acompanhar por este aviso.

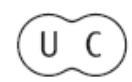



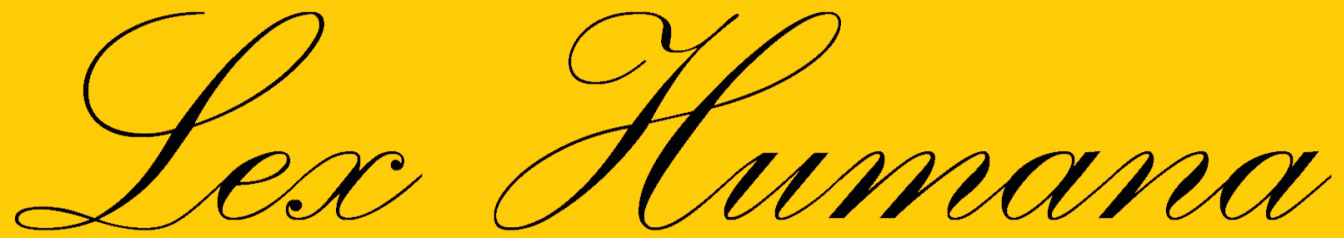

Revista do Programa de Pós-Graduação em Direito da UCP

ISSN(e) 2175-0947

Universidade Católica de Petrópolis Rua Benjamin Constant, 213 - Petrópolis - Centro CEP 25610-130

Tel: (24) 2244-4000 E-mail: lexhumana@ucp.br 


\section{Um Breve Panorama das Relações entre Política e Religião no Contexto do Estado Moderno}

Dr. Marco Aurélio Lagreca Casamasso ${ }^{1^{*}}$

Resumo

O artigo objetiva proporcionar, a partir da perspectiva do pensamento político moderno, um breve panorama do modelo de relação que se estabelece entre a política e a religião no contexto do Estado Moderno. Destaca-se a hegemonia do poder estatal no âmbito da sociedade política e, em particular, sua supremacia em face da religião e dos atores religiosos. Apresenta-se um relato sucinto da problemática político-religiosa no pensamento de Maquiavel, Hobbes, Spinoza, Locke, Montesquieu e Rousseau.

Palavras-chave: política e religião no pensamento político moderno; Estado e Igreja; Estado Moderno e religião.

Abstract

This article aims to provide, based on the modern political

1 Doutor em Direito do Estado pela PUC-SP e Mestre em Teoria do Estado e da Constituição pela PUC-RIO. Atualmente é Professor dos Cursos de Direito da UCP, do IBMEC e da UCAM.

http://www.ucp.br/html/joomlaBR/lexhumana/lexhumana.htm 
thought, a brief outline of the relationship between politics and religion on the context of the Modern State. It is emphasized the hegemony of the State in regard to the political society and, particularly, the supremacy over religion as well as the religious actors. It is also given a concise description of the political religious issues on the thinking of Machiavelli, Hobbes, Spinoza, Locke, Montesquieu and Rousseau.

Keywords: Politics and religion in modern political thought; Church and State; Modern State and religion.

\section{Introdução}

O presente artigo visa a apresentar um breve panorama concernente à configuração das relações entre o Estado e a religião que emerge do pensamento político moderno. Pretende-se esboçar os contornos da moderna solução para o enfrentamento do milenar conflito político-religioso, cujas consequências implicarão, na arena política, o avanço e a supremacia do poder estatal em franco contraste com o recuo do poder espiritual.

Amiúde referida como portadora de um projeto que estabelece, 
a partir da idéia de separação, ${ }^{2}$ campos de atuação distintos para os atores políticos e religiosos, a modernidade ${ }^{3}$ caracteriza-se, sobretudo, como instauradora de uma nova hierarquia de poderes, centrada na preeminência do poder estatal em face de quaisquer outros poderes, inclusive o religioso. De fato, no âmbito do mundo ocidentalizado, a separação entre o Estado e as confissões religiosas não se apresenta como padrão imune a exceções. ${ }^{4}$ Mais do que a concretização de uma separação, é o aspecto da supremacia do poder estatal que se mostra decisivo na conformação da religião na modernidade, e, por extensão, na época contemporânea, com reflexos diretos sobre a dimensão e o modo de exercício da liberdade religiosa.

A despeito da complexidade do tema objeto deste estudo, e das limitações daí decorrentes, procura-se oferecer alguns

2 De acordo com Pierre Manent, é possível explicar o processo deflagrado pela modernidade aludindo-se a movimentos de ruptura, identificados e caracterizados com base em seis "categorias amplas de separação", que teriam engendrado e condicionado a modernidade: a separação das profissões, ou divisão do trabalho; a separação dos poderes; a separação entre a Igreja e o Estado; a separação entre a sociedade civil e o Estado; a separação entre o representado e o representante; e, a separação entre fatos e valores, ou entre a ciência e a vida. O autor refere tais "categorias amplas de separação" tendo em vista a formação da democracia moderna. Entendemos, todavia, que tais categorias devam ser estimadas em um contexto mais amplo, repercutindo sobre outros aspectos da modernidade. Esses movimentos de separação, explica o autor, não são estanques. No decorrer da história, eles surgiram sobrepondo-se uns aos outros. Típica sobreposição é a que envolve as separações entre a sociedade civil e o Estado, de um lado, e entre a Igreja e o Estado, de outro. Neste caso, a última separação seria uma espécie da primeira. Além das sobreposições, vale ressaltar o fato de que o desenvolvimento das separações referidas por Manent não ocorreu em sincronia. O movimento de separação entre a Igreja e o Estado, por exemplo, iniciou-se, ainda que timidamente, bem antes do movimento filosófico que culminou na separação entre fatos e valores. Pierre Manent, Curso de Filosofía Política, Buenos Aires: Fondo de Cultura Económica, 2003 , pp. 21 e 22.

3 Considera-se a modernidade como o período que se inicia no século XVI e se estende até as revoluções liberais do século XVIII, na Europa, compreendendo sucessivos eventos filosóficos, políticos, religiosos, científicos, econômicos e artísticos, que provocaram a erosão da ordem cristã medieval. Cf. Carlos Altamirano, Modernidad, in: Torcuato di Tella, et. al. , Diccionario de ciencias sociales y políticas, Buenos Aires: Emecé, 2001, p. 468.

4 Os casos da Inglaterra, com a Igreja Anglicana, e da Dinamarca, com a Igreja Evangélica Luterana, são exemplos de união entre o Estado e a Igreja que permaneceram no contexto do Estado moderno. Entretanto, isso não significa que suas respectivas sociedades não tenham sido alcançadas pelo movimento da secularização. Veja-se, por todos, Ole Riis, State Churches, in Robert Wuthnow (Ed.), The Encyclopedia of politics and religion, vol. II, Washington D.F.: Congressional Quarterly, 1998: 714-716. 
referenciais para a reflexão acerca do espaço reservado à religião em um mundo dividido e dominado pelos Estados soberanos. Neste sentido, considerou-se oportuno realçar os traços mais relevantes da problemática político-religiosa nos pensamentos de Maquiavel, Hobbes, Spinoza, Locke, Montesquieu e Rousseau.

\section{O Estado Moderno}

O Estado Moderno representa a supremacia da política no contexto da sociedade humana. ${ }^{5}$ Resultado da concentração do poder político nas mãos do monarca absolutista em detrimento do sistema poliárquico medieval, ele surgirá na Europa Ocidental em fins da Idade Média e início da modernidade ${ }^{6}$ como uma instituição política modelar, que, nos séculos seguintes, se irradiará para outros continentes. Dotado do monopólio do uso da força física e de um poder soberano, o Estado Moderno assume a condição de autoridade em última instância, impondo-se como o poder acima de todos os outros poderes situados em um território determinado. Em termos pragmáticos, a soberania lhe permitirá não apenas estabelecer e proteger as suas fronteiras, mas também controlar, por intermédio do monopólio da força física e da produção do direito, todas as atividades - religiosas, políticas, econômicas, científicas, culturais etc.

\footnotetext{
5 O Estado Moderno representa o modelo de instituição política que mais sucesso alcançou na concretização das características do poder político, entendido como o monopólio do uso da força física nos limites de um território determinado. Uma forma de constatarmos esse sucesso é contrastarmos o modelo estatal que emerge da Modernidade - detentor de um amplo e efetivo controle sobre os mais variados setores da sociedade graças à sua unidade político-jurídica lastreada no monopólio da força física - com o sistema político medieval, cuja feudalização e poliarquia impediram o desenvolvimento de um controle pleno e uniforme sobre a totalidade dos indivíduos situados sobre o seu território. Para o aprofundamento deste contraste, veja-se, por exemplo, a análise dos pressupostos históricos do Estado atual, apresentada por Hermann Heller, Teoría del Estado, México D.F.: Fondo de Cultura Económica, 1992, pp. 141-154.

6 Cf. Pierangelo Schiera, Estado Moderno, in: Norberto Bobbio, Nicola Matteucci e Gianfranco Pasquino, (Orgs.) Dicionário de Política, v. 2, 4.ed., Brasília: Edunb, 1992 , pp. 425-431.
} 
- praticadas pelos indivíduos e grupos que atuam no perímetro do seu espaço territorial.

No que se refere ao relacionamento com a religião, e, em particular, com a Igreja, o Estado Moderno procurará romper os laços que o condicionavam - ou subordinavam -, ao controle das autoridades eclesiásticas. Esse rompimento é conexo ao imperativo de se fundar e legitimar a coesão dos seus membros - os cidadãos não nas crenças e valores religiosos, mas na razão de ser do próprio Estado, isto é, no fato de que a existência do poder estatal impõese como conditio sine qua non para a garantia da segurança, da paz e da prosperidade econômica. ${ }^{7}$ Produz-se, assim, um novo arranjo no feixe de lealdades do homem ocidental moderno: a obediência primeira, decisiva e derradeira é devida ao Estado, cabendo às outras instituições - comunidade, família, grupo, corporação, confissão religiosa etc. - uma lealdade secundária, e isto, quando autorizada pelo poder estatal. ${ }^{8}$

A pujança e a superioridade do Estado manifestam-se inclusive em algumas das doutrinas políticas formuladas em torno de argumentos teológicos, elaboradas após o século XVI. Na Inglaterra, por exemplo, Robert Filmer, na obra Patriarcha, publicada em 1680, fundamenta o poder político recorrendo aos desígnios divinos e a um modelo familial e paternalista de organização da sociedade política. Segundo o autor inglês, os direitos de governar da monarquia do seu tempo derivariam de uma linha política sucessória iniciada por

7 Joseph Strayer descreve a novidade - contrastando com o sistema político medieval - e a importância do Estado Moderno nos seguintes termos: "Um homem pode levar uma vida razoavelmente sem família, sem um local fixo de residência, ou sem uma filiação religiosa. Mas sem Estado ele não é nada. Ele não tem direitos, segurança, e a mínima oportunidade para exercer uma carreira útil. Não há salvação na terra fora do âmbito de um Estado organizado". On the Origins of the Modern State, Pincenton: Princenton University Press, 1973, p. 3.

8 Christopher Morris, The Modern State, in Handbook of Political Theory, Sage Publications. Disponível em: <http://www.sage-ereference.com/hdbk_poltheory/Article_n15.html>. Acesso em 5.04.2010. 
Adão, primeiro herdeiro de Deus, e também primeiro rei. ${ }^{9} \mathrm{Na}$ França, Bossuet, na sua Política tirada da Sagrada Escritura, advoga em defesa do absolutismo monárquico, identificando a obediência ao rei à obediência a Deus, e a desobediência ao poder real com o desrespeito à vontade divina. ${ }^{10}$ Mas a despeito do vínculo teológico-político que se pretendia legitimar, o que ficou mais evidente nessas doutrinas foi o fortalecimento do próprio poder político, ainda que a custa de uma flagrante instrumentalização da religião.

Embora concisa, a seleção de obras abaixo arrolada proporciona uma amostra significativa do que representou, em linhas gerais, a religião para o Estado, no domínio do pensamento político moderno.

3. Comentários sobre a primeira década de Tito Lívio (1513-1519), de Nicolau Maquiavel

Na obra Comentários sobre a primeira década de Tito Livio, Maquiavel (1469-1527) avalia a dupla potencialidade da religião no mundo da política: a de operar como instrumento indispensável para a fundação e permanência das sociedades políticas e a de deslegitimar os Estados. Apesar de o autor florentino referir-se, em especial, às questões políticas enfrentadas pelos antigos romanos, pode-se estender a sua análise a um contexto político bem mais amplo - compreendendo o Estado Moderno e a própria política contemporânea -, porquanto, na qualidade de instrumentum regni, a religião tem sido empregada como espécie de ferramenta intemporal, de utilização recorrente entre governos de orientações ideológicas as mais diversas.

9 Jean-Jacques Chevallier, História do Pensamento Político, tomo 2, Rio de Janeiro: Guanabara Koogan, 1983, p. 39.

$10 \quad$ Idem, pp. 16 e 17.

http://www.ucp.br/html/joomlaBR/lexhumana/lexhumana.htm 
Maquiavel tem plena noção do caráter instrumental que assume a religião em relação à política. Destarte, chega a avaliá-la com base no critério de possuir uma boa ou uma má serventia para o Estado. Cioso da estabilidade política, ele reconhece a importância decisiva da religião como elemento de coesão e de civilidade para o povo. Nada obstante esse benefício, o autor florentino não deixa de denunciar os efeitos deletérios causados pelos rumos tomados pelo cristianismo, que, tendo desprezando o mundo terrestre - real e imperfeito -, em favor do mundo celestial - ideal e perfeito -, acabou provocando a derrocada de Estados.

Maquiavel dedica alguns dos capítulos dos seus Comentários à religião, ${ }^{11}$ destacando o seu caráter instrumental do ponto de vista político. A indispensabilidade do fator religioso para a estabilidade política é patente no pensamento maquiaveliano: "aquele que encontrando um povo muito feroz e querendo reduzilo à obediência civil com as artes da paz, voltou-se para a religião como coisa completamente necessária em se tratando de querer manter a civilização...". ${ }^{12}$ Em outra passagem dos Comentários, o conselho dirigido aos governantes é claro: "aqueles príncipes ou aquelas repúblicas que querem manter-se incorruptíveis, têm acima de tudo de manter incorruptível as cerimônias da sua religião, e ter sempre nela a sua veneração" ${ }^{13}$ Ainda à guisa de ilustração, a defesa do caráter instrumental da religião pode ser encontrada no título do capítulo XIII do Livro I: “Como os romanos se serviram da religião para reordenarem a cidade e assegurarem suas empresas e acabarem

\footnotetext{
11 Niccololò Machiavelli, Discorsi sopra la prima deca di Tito Livio in: Il principe e altre opere poiltiche, Milano: Garzanti, 1981, caps. XI a XV do Livro I, pp. 131 e ss.

12 Idem, I, cap. XI, p. 138.

13 Idem, Livro I, cap. XII, p. 141.

http://www.ucp.br/html/joomlaBR/lexhumana/lexhumana.htm
} 
com os tumultos" ${ }^{14}$

Muito embora a tenha valorizado como instrumento de estabilidade política, Maquiavel não desconheceu a possibilidade de a religião operar em sentido inverso, transformando-se em instrumento lesivo à estabilidade política e à grandeza do Estado, e atuando, desse modo, como autêntico elemento de deslegitimação. Este é o caso do papel que o cristianismo teria desempenhado ao longo do processo de declínio do Império Romano. Conquanto não tenha chegado a identificar no cerne do cristianismo a existência de fatores corrosivos para a política, o autor reconhece o seu efeito devastador sobre as estruturas do Estado pelo fato de o cristianismo ter sido interpretado de acordo com a "indolência", e não de acordo com a "virtù". Eis que ao referir-se ao cristianismo Maquiavel afirma que "a nossa religião glorificou mais os homens humildes e contemplativos do que os de ação", e "instituiu como o maior dos bens a humildade, a capacidade de se rebaixar e o desprezo pelas coisas humanas". Este modo de viver, conclui o autor, "tornou o mundo fraco, entregando-o como presa à rapina de homens perversos". ${ }^{15}$

Ao criticar o Cristianismo, Maquiavel desfere golpe contra a Igreja Católica. Grande ator na cena política renascentista, a Igreja portava-se como um poder político pujante e independente, em um cenário repleto de repúblicas e principados relativamente fragilizados. O problema, segundo Maquiavel, é que embora a Igreja fosse suficientemente forte para fomentar a instabilidade política por toda a península itálica, não era forte o suficiente para garantir a unidade, isto é, não era capaz de unir a Itália "sob uma só cabeça", o que fazia dela - da Península Itálica -“uma presa não apenas para os

\footnotetext{
14 Idem, Livro I, cap. XIII, p. 144.

15 Idem, Livro II, cap. II, pp. 251 e 252.

http://www.ucp.br/html/joomlaBR/lexhumana/lexhumana.htm
} 
poderosos bárbaros, mas para qualquer um que devesse assaltá-la". ${ }^{16}$

4. Leviatã (1651), de Thomas Hobbes

A mudança nas relações entre o Estado e a Igreja que se anuncia com o advento da modernidade encontra em Thomas Hobbes (1588-1679) um dos seus grandes intérpretes. Na teoria contratualista hobbesiana, apresentada na obra Leviatãa, a superação da anarquia e da insegurança do estado de natureza ${ }^{17}$ - período da existência humana marcado pela ausência da civilização, da política e das noções de justo e injusto ${ }^{18}$ - só pode ser alcançada por intermédio de um poder absoluto, a ser instituído por ocasião do pacto a ser celebrado por todos os indivíduos. ${ }^{19}$ Pessimista em relação aos seres humanos, individualmente considerados seres egoístas dedicados apenas à promoção dos próprios interesses, Hobbes não crê na possibilidade do alcance e da manutenção da paz sem a existência de um Estado absoluto, capaz de frear as inevitáveis paixões dos homens e de anular o relativismo, produto do individualismo nominalista, a respeito das concepções de bem e de mal. No seu modelo de sociedade política, não há lugar para quaisquer disputas doutrinárias - políticas, religiosas etc. -, naturalmente nocivas à estabilidade política. Daí que compete ao soberano "ser juiz de quais as opiniões e doutrinas que são contrárias à paz, e quais as que lhe são propícias" ${ }^{20}$

\footnotetext{
$16 \quad$ Idem, Livro I, cap. XII, p. 144.

17 No estado de natureza hobbesiano “...não há sociedade; e o que é pior do que tudo, um constante temor e perigo de morte violenta. E a vida do homem é solitária, pobre, sórdida, embrutecida e curta". Thomas Hobbes, Leviatã, 3. ed., Coleção os Pensadores, São Paulo, Abril Cultural, 1983, Livro I, cap. XIII, p. 76.

18 Afirma Hobbes que no estado de natureza "as noções de bem e de mal, de justiça e injustiça, não podem aí ter lugar". Idem, p. 77.

19 Idem, Livro II, cap. XVII, pp. 103 e ss.

20 Idem, cap. XVIII, p. 109.

http://www.ucp.br/htmlljoomlaBR/lexhumana/lexhumana.htm
} 
Corriqueiras na Europa dos séculos XVI e XVII, as guerras de religião representavam um alto risco para a paz. Espectador atento dos conflitos político-religiosos, Hobbes não admite divergências e incompatibilidades entre os comandos político e religioso: "os súditos devem aos soberanos simples obediência em todas as coisas, de onde se segue que sua obediência não é incompatível com as leis de Deus...". ${ }^{21}$ Embora não deixe de reconhecer a distinção entres as esferas política e espiritual, ${ }^{22}$ e a existência de um culto interior - de competência exclusiva dos súditos considerados individualmente e de um culto exterior, isto é, público, ${ }^{23}$ a solução do filósofo inglês para problema teológico-político não deixa dúvidas quanto à nova hierarquia que se delineia com o advento Estado Moderno: ao soberano caberá a condução das questões relativas à religião.

A fim de impedir que a "águia de duas cabeças" - metáfora utilizada para indicar a concomitância da atuação dos poderes "soberanos" do Estado e da Igreja na sociedade, - provocasse indefinições e dúvidas quanto à obediência devida ao Estado, e, consequentemente, conflitos e guerras, Hobbes propõe que a Igreja se transforme em uma espécie de órgão estatal: "aqueles atributos que o soberano ordena, no culto de Deus, como sinais de honra, devem ser aceites e usados como tais pelos particulares em seu culto público". ${ }^{24}$ Em suma, “dado que um Estado é apenas uma pessoa, deve também

\footnotetext{
21 Idem, cap. XXXI, p. 211.

22 Hobbes dedica o capítulo XXXI do Livro II do Leviatã ao "reino de Deus por natureza". Idem, pp. 211. e ss.

23 Afirma Hobbes que "há um culto público e um culto privado. Público é o culto que um Estado realiza como pessoa. Privado é aquele que é feito por um particular. O público, no que se refere a todo o Estado, é livre, mas no que se refere aos particulares não o é. O culto privado é secretamente livre, mas perante a multidão nunca existe sem algumas restrições...”. É interessante observar que o fato de o culto ser livre para o Estado significa, na prática, a submissão da religião à vontade do soberano. Idem, p. 214.

$24 \quad$ Idem, p. 217.
}

http://www.ucp.br/html/joomlaBR/lexhumana/lexhumana.htm 
apresentar a Deus um só culto". ${ }^{25}$ Assim, a proposta de Hobbes para o alcance da paz por intermédio do poder absoluto só será bem sucedida se aquele a quem for atribuído a tarefa de governar consiga neutralizar o fator religioso como fonte de obediência independente do Estado.

\section{Tratado teológico-político (1670), de Baruch Spinoza}

A preeminência do poder estatal em face da religião também está presente no Tratado teológico-político, de Spinoza (1632-1677). Contratualista, o filósofo holandês concebe Estado soberano - produto do choque das paixões humanas -, como tendo sido criado a partir da transferência pelos indivíduos do poder que detinham no estado de natureza. ${ }^{26}$ Não submetida a nenhuma $l e i^{27}$ a soberania é equiparada a um "direito absoluto de natureza", capaz de exercer um "poder sobre todas as coisas", de maneira que "cada um está obrigado a obedecêla, seja de modo livre, seja pelo temor do suplício", ${ }^{28}$ devendo ser essa obediência "absoluta e ilimitada." 29

A despeito da soberania absoluta, os indivíduos devem estar em condições de usufruir as liberdades de consciência e de expressão, no âmbito da sociedade democrática propugnada por Spinoza. ${ }^{30} \mathrm{Nesse}$ contexto, a democracia spinoziana deve ser hábil para promover o equilíbrio entre as liberdades e a harmonia pública. É na consecução

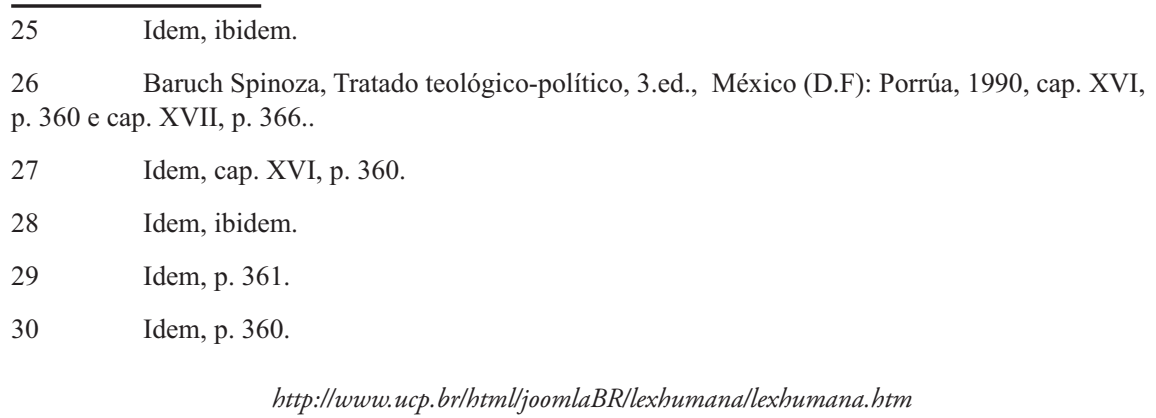

http://www.ucp.br/html/joomlaBR/lexhumanallexhumana.htm 
dessa tarefa que desponta um soberano democrático incumbido da religião.

Spinoza distingue o culto interior do culto exterior. O primeiro deve ficar a cargo exclusivo de cada indivíduo, e não de uma "vontade alheia". ${ }^{31}$ Cada um, por conseguinte, poderá, por si mesmo, interpretar as Sagradas Escrituras como bem lhe aprouver. ${ }^{32}$ Mas no exercício dessa liberdade de culto interior não poderão os indivíduos reivindicar o direito de torná-lo público, sob pena de ameaça à ordem pública. $^{33}$

O culto exterior, por seu turno, deve ser estabelecido, organizado e regulado pelo Estado, em conformidade com a tranquilidade e a utilidade pública: ${ }^{34}$ "a religião só adquire força de lei por força do decreto dos que possuem o direito de mandar, e Deus não pode fundar seu reino entre os homens senão por meio do soberano". ${ }^{35}$ Ao afirmar o direito de o soberano estatuir sobre a religião, Spinoza não apenas confirma a moderna hegemonia estatal, como também afasta o fantasma das guerras de religião

6. Carta acerca da tolerância (1689), de John Locke

Para Locke (1632-1704), há uma clara distinção entre Igreja e Estado. Possuidores de competências distintas e bem definidas, caberá à primeira cuidar dos cultos e ritos religiosos, e ao segundo

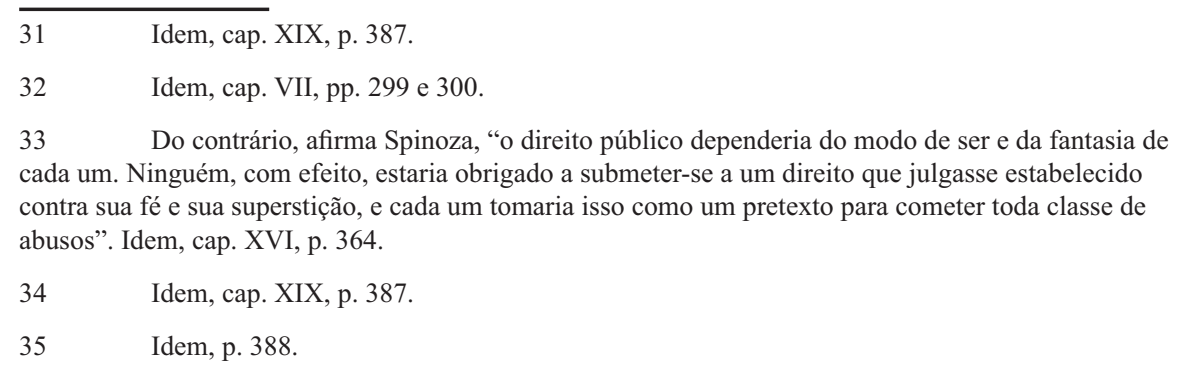

http://www.ucp.br/html/joomlaBR/lexhumana/lexhumana.htm 
garantir a conservação dos homens e das suas propriedades. ${ }^{36}$ Assim, as Igrejas não poderão exigir a renúncia ou a deposição de um monarca excomungado, e os Estados não deverão se imiscuir nas atividades eclesiásticas.

Na Carta acerca da tolerância, tal distinção assume um caráter mais pragmático, expresso na defesa da liberdade religiosa, a ser reconhecida e protegida em um regime de tolerância. Todavia, na perspectiva adotada por Locke, a consagração de uma autêntica liberdade religiosa sofre uma mitigação, admitindo-se a intervenção do poder estatal nas questões de crença. Eis que o filósofo inglês é categórico ao negar a tolerância aos católicos, asseverando que a Igreja de Roma não possui "o direito de ser tolerada pelo magistrado, pois se constitui de tal modo que todos seus membros ipso facto se transformam em súditos e serviçais de outro príncipe ${ }^{\prime \prime} \cdot{ }^{37}$ Essa negação visa a evitar o conflito entre os deveres civis e religiosos, em prol da preservação e da garantia da obediência política.

Ora, de quem seria a incumbência de bani-los - os católicos - da sociedade? Acaso não seria do detentor do poder político? Na prática, a defesa dessa intolerância nada mais é do que a defesa da ascendência do político sobre o religioso. Além de não admitir a presença dos católicos na sociedade, Locke prescreve a intolerância em relação aos ateus: "os que negam a existência de Deus não devem ser de modo algum tolerados". ${ }^{38}$ Isto porque "as promessas, os pactos e os juramentos, que são os vínculos da sociedade humana, para um ateu não podem ter segurança ou santidade, pois a supressão de

\footnotetext{
36 John Locke, Carta acerca da tolerância, 2.ed., Coleção os Pensadores, São Paulo: Abril Cultural, 1978, pp. 5 e 6.

$37 \quad$ Idem, p. 23.

$38 \quad$ Idem, pp. 23 e 24.

http://www.ucp.br/html/joomlaBR/lexhumana/lexhumana.htm
} 
Deus, ainda que apenas em pensamento, dissolve tudo" ${ }^{39}$

Ao não tolerar os católicos e os ateus, Locke acaba pondo a descoberto os limites da complexidade do problema teológicopolítico: de um lado, ao proscrever os católicos, reconhece o potencial de deslegitimação que a religião poderá desenvolver em face do governante, estimulando entre os súditos uma obediência paralela, nociva à estabilidade política; por outro lado, ao não tolerar os ateus, reconhece a necessidade da religião como fermento para a coesão social e política da sociedade. A mensagem de Locke sobre as relações entre o Estado e a Igreja não chega, portanto, à defesa de uma plena autonomia para esta última.

\section{Do espírito das leis (1748), de Baron de Montesquieu}

Ao voltar-se para a análise das relações entre as leis divinas e as leis humanas, Montesquieu (1689-1755) reconhece, na obra Do espírito das leis, duas competências distintas: "não se deve de modo algum estatuir pelas leis divinas o que deve sê-lo pelas leis humanas...". ${ }^{40}$ A distinção de competências, contudo, não impede o autor de considerar a religião a partir da perspectiva do instrumentum regni: "só examinarei, portanto, as diversas religiões do mundo em relação ao bem que delas se tira no estado civil" . ${ }^{41}$ Neste sentido, Montesquieu avalia a conveniência política do cristianismo, do protestantismo e do islamismo. ${ }^{42}$

\footnotetext{
39 Idem, ibidem.

40 Montesquieu, Do espírito das leis, 2.ed. Coleção os Pensadores. São Paulo: Abril Cultural, 1979, Livro XXVI, cap. II, p.391.

41 Idem, Livro XXIV, cap. I, p. 365.

42 Idem, pp. 366 e 367 . O cristianismo, por exemplo, está afastado "do puro despotismo: é que, sendo a brandura tão recomendada no Evangelho, ela se opõe à cólera despótica com a qual o príncipe faria justiça e exerceria suas crueldades". Idem, p. 366.

http://www.ucp.br/html/joomlaBR/lexhumana/lexhumana.htm
} 
Para Montesquieu, a religião deve ser utilizada tendo em vista a estabilidade política: "a religião pode sustentar o Estado político quando as leis se acham na impotência". ${ }^{43}$ E acrescenta, em seguida: "assim, quando o Estado é amiúde agitado por guerras civis, a religião muito fará se estabelecer que alguma parte deste Estado permaneça sempre em paz".

A instrumentalização política da religião é ratificada, quando Montesquieu trata da tolerância religiosa. ${ }^{44}$ Primeiramente é preciso que as diversas religiões existentes na sociedade tolerem-se mutuamente, o que pode, se necessário, ser garantido pelas próprias leis estatais. ${ }^{45}$ Em segundo lugar, e aqui se revela a indubitável supremacia da política em face da religião, é indispensável que as religiões toleradas "não perturbem o Estado". ${ }^{46}$ A fim de evitar esse inconveniente, não raro devastador para as sociedades políticas, Montesquieu reduz drasticamente a dimensão da sua concepção de tolerância. Destarte, afirma o autor, seria uma "lei civil muito boa quando o Estado está satisfeito com a religião já estabelecida, não permitir o estabelecimento de outra" ${ }^{47}$

8. Do contrato social (1762), de Jean-Jacques Rousseau 
Na obra Do contrato social Rousseau (1712-1778) distingue três tipos de religião. ${ }^{48}$ A primeira, a religião do homem, equipara-se ao culto interior. A segunda, a religião do cidadão, é identificada com as religiões da Antigüidade, que correspondiam aos cultos, dogmas e ritos de uma nação e que não se estendiam a outras. A terceira, que poderia ser denominada religião dos sacerdotes, equivale às religiões dos lamas tibetanos e do cristianismo romano. ${ }^{49}$ Embora atribua defeitos às três religiões, é a terceira que Rousseau destaca - e aqui, como calvinista que era, ele visa a atacar o catolicismo -, por ser "tão evidentemente má, que se perde tempo no divertimento de demonstrá-1o" ${ }^{50}$

A razão de tamanha fúria contra a Igreja Católica é o fato de ela ser um fator de risco para a unidade do Estado. Ao estabelecer uma relação de obediência autônoma com os súditos do Estado, o catolicismo incitaria divisões no seio da sociedade, já que nem sempre os seus interesses estariam em conformidade com os interesses expressos pela vontade de todo o corpo político, ou seja, pela "vontade geral" .51

Assim, ao avaliar o catolicismo, Rousseau é implacável: “tudo o que rompe a unidade social, nada vale" ${ }^{52}$ Sem julgar inconveniente a prática da religião do homem, já que esta consiste em um culto interior, Rousseau propõe, seguindo o modelo das religiões da Antigüidade, uma religião civil que servisse de base para reforçar a sedimentação

\footnotetext{
48 Jean Jacques-Rousseau, Do contrato social, 2.ed. Coleção os Pensadores. São Paulo: Abril Cultural, 1978, Livro IV, cap. VIII, p. 141.

49 Idem, ibidem.

$50 \quad$ Idem, ibidem.

51 Na obra Do contrato social, o soberano, que é o povo, possui uma vontade, denominada "vontade geral", que deverá prevalecer, na sociedade política, acima de todas as outras vontades. Rousseau contrapõe à "vontade geral" não apenas a vontade de cada um dos súditos em particular, mas também a vontade do próprio governo, cuja vontade seria, segundo ele, particular em relação à vontade do povo, isto é, do soberano. Idem, Livro I, caps. VI e VII.

52 Idem, Livro IV, cap. VIII, p. 141.

http://www.ucp.br/html/joomlaBR/lexhumana/lexhumana.htm
} 
social do Estado instituído pelo pacto entre os indivíduos.

Semelhante à solução de Hobbes, a proposta rousseauniana para impedir o conflito entre as obediências política e religiosa é simplesmente fazer com que a primeira absorva a segunda. Deste modo, o soberano estabeleceria uma "profissão de fé puramente civil", cujos artigos, seriam por ele fixados, "não precisamente como dogmas de religião, mas como sentimentos de sociabilidade sem os quais é impossível ser bom cidadão ou súdito fiel" ${ }^{53}$ Quanto à tolerância, todas as religiões tolerantes devem ser toleradas, "contanto que seus dogmas em nada contrariem os deveres do cidadão". ${ }^{54}$ Consequentemente, os interesses do Estado serão sempre um critério decisivo para admissão ou não da liberdade religiosa.

\section{Considerações finais}

A despeito das significativas diferenças, as concepções que apresentamos sobre as relações entre o Estado e a religião revelam três importantes aspectos em comum. O primeiro diz respeito ao fato de Maquiavel, Hobbes, Spinoza, Locke, Montesquieu e Rousseau reconhecerem a existência de duas esferas de ação distintas: a política e a religiosa. Todos são cônscios de que esta dicotomia políticoreligiosa engendra os perigos de uma obediência bipartida, cuja ambiguidade pode por em risco a segurança do Estado.

O segundo aspecto comum é o fato de estes autores reconhecerem o caráter instrumental da religião em face ao Estado. Ou seja, todos eles têm plena consciência tanto do potencial de legitimação, quanto do potencial de deslegitimação da religião. Assim, é em função deste duplo potencial de legitimação/deslegitimação

\footnotetext{
$53 \quad$ Idem, pp. 143 e 144.

$54 \quad$ Idem, p. 145.

http://www.ucp.br/htmlljoomlaBR/lexhumana/lexhumana.htm
} 
que a religião deve ser estimada pelos governantes. Isto explica, por exemplo, porque Maquiavel, por um lado, elogia a religião, ou melhor, o bom uso que dela fizeram os governantes romanos para se manterem no poder, e, por outro, condena-a, quando repudia o sentido negativo que o cristianismo teria assumido para a política, por conta de ter se tornado objeto de uma interpretação por ele julgada equivocada. $\mathrm{O}$ mesmo tipo de duplicidade pode ser encontrado em Locke, ao considerar os ateus e os católicos não merecedores da tolerância por parte do Estado - estes, por praticarem uma religião nociva à estabilidade política, e aqueles, por não praticarem a religião, tão necessária à coesão social.

O terceiro aspecto decorre diretamente do anterior: a instrumentalização da religião nada mais é do que a consagração da supremacia do Estado. Nos autores mencionados, verifica-se uma aguerrida defesa da unidade política, ainda que seja por intermédio da utilização de um poder político limitado - mas não fragilizado -, como em Locke e Montesquieu. Ora, é em defesa do fundamento e da estabilidade da unidade política que a religião deve ser admitida no seio da sociedade. Por essa razão, mesmo que se pratique a tolerância, as religiões só deverão ser aceitas se forem compatíveis com a segurança e os interesses do Estado. Ou seja, em uma situação limite, a liberdade e a pluralidade deverão ceder em prol da unidade política. Assim, por exemplo, ao mesmo tempo em que defendem a tolerância, Hobbes, Spinoza, Locke, Montesquieu e Rousseau acabam por subordiná-la às exigências da estabilidade política.

Referências Bibliográficas

ALTAMIRANO Carlos, Modernidad. In: DI TELLA, Torcuato, et. al., Diccionario de ciencias sociales y políticas. Buenos Aires: Emecé, 2001: 
$468-471$.

CHEVALLIER, Jean-Jacques. História do Pensamento Político, tomo 2, Rio de Janeiro: Guanabara Koogan, 1983, p. 39.

HELLER, Hermann. Teoría del Estado. Buenos Aires: Fondo de Cultura Económica, 1992.

HOBBES, Thomas. Leviatã, 3. ed. Coleção os Pensadores. São Paulo: Abril Cultural, 1983.

LOCKE, John. Carta acerca da tolerância. Coleção os Pensadores. São Paulo: Abril Cultural, 1978.

MACHIAVELLI, Niccolò. Discorsi sopra la prima deca di Tito Livio. In: Il principe e altre opere poltiche. Milano: Garzanti, 1981.

MANENT, Pierre. Pierre. Curso de Filosofía Política. Buenos Aires: Fondo de Cultura Económica, 2003.

MONTESQUIEU, Baron de. Do espírito das leis. 2.ed. Coleção os Pensadores. São Paulo: Abril Cultural, 1979.

MORRIS, Christopher. The Modern State. In Handbook of Political Theory, Sage Publications. Disponível em: <http:/ / www.sageereference.com/hdbk_poltheory/Article_n15.html>. Acesso em 5.10.2010.

RIIS, Ole. State Churches, in WUTHNOW, Robert (Ed.), The Encyclopedia of politics and religion, vol. II, Washington D.F.: Congressional Quarterly, 1998: 714-716.

ROUSSEAU, Jean-Jacques. Do contrato social. 2.ed. Coleção os Pensadores. São Paulo: Abril Cultural, 1978.

SCHIERA, Pierangelo. Estado Moderno. In: BOBBIO, Norberto, 
MATTEUCCI, Nicola e PASQUINO, Gianfranco (Orgs.) Dicionário de Política, v. 2, 4.ed. Brasília: Universidade de Brasília, 1992: 425-431.

SPINOZA, Baruch. Tratado teológico-político. 3.ed. México (D.F): Porrúa, 1990.

STRAYER, Joseph. On the origins of the Modern State. Princeton: Princeton University Press, 1973. 